\title{
Physiology of Glyphosate-Resistant and Glyphosate-Susceptible Palmer Amaranth (Amaranthus palmeri) Biotypes Collected from North Carolina
}

\author{
Jared R. Whitaker, ${ }^{1}$ James D. Burton, ${ }^{2}$ Alan C. York, ${ }^{3}$ David L. Jordan, ${ }^{3}$ and Aman Chandi ${ }^{3}$ \\ ${ }^{1}$ Department of Crop and Soil Sciences, University of Georgia, P.O. Box 8112, Statesboro, GA 30460, USA \\ ${ }^{2}$ Department of Horticultural Science, North Carolina State University, Box 7609, Raleigh, NC 27695, USA \\ ${ }^{3}$ Department of Crop Science, North Carolina State University, Box 7620, Raleigh, NC 27695-7620, USA
}

Correspondence should be addressed to David L. Jordan; david_jordan@ncsu.edu

Received 11 April 2013; Accepted 8 July 2013

Academic Editor: Kent Burkey

Copyright ( 2013 Jared R. Whitaker et al. This is an open access article distributed under the Creative Commons Attribution License, which permits unrestricted use, distribution, and reproduction in any medium, provided the original work is properly cited.

\begin{abstract}
Glyphosate-resistant (GR) biotypes of Palmer amaranth are now commonly found across the southern United States. Experiments were conducted to characterize physiological differences between a GR biotype and a glyphosate-susceptible (GS) biotype from North Carolina. The GR biotype had an 18-fold level of resistance based upon rates necessary to reduce shoot fresh weight $50 \%$. Shikimate accumulated in both biotypes following glyphosate application, but greater concentrations were found in GS plants. Absorption and translocation of ${ }^{14} \mathrm{C}$-glyphosate were studied in both biotypes with and without an overspray with commercial glyphosate potassium salt $\left(840 \mathrm{~g}_{\text {ae }} \mathrm{ha}^{-1}\right)$ immediately prior to ${ }^{14} \mathrm{C}$-glyphosate application. Greater absorption was noted $6 \mathrm{~h}$ after treatment (HAT) in GS compared with GR plants, but no differences were observed at 12 to 72 HAT. Oversprayed plants absorbed 33 and $61 \%$ more ${ }^{14} \mathrm{C}$ by 48 and $72 \mathrm{HAT}$, respectively, than plants not oversprayed. ${ }^{14} \mathrm{C}$ distribution (above treated leaf, below treated leaf, roots) was similar in both biotypes. Together, these results suggest that resistance in this biotype is not due to an altered target enzyme or translocation but may be in part due to the rate of glyphosate absorption. These results also are consistent with resistance being due to increased gene copy number for the target enzyme.
\end{abstract}

\section{Introduction}

Palmer amaranth is the most troublesome weed for cotton (Gossypium hirsutum L.) and soybean (Glycine max (L.) Merr.) producers in much of the southern United States [1]. Glyphosate has traditionally been effective in controlling Palmer amaranth $[2,3]$, and excellent control has been achieved in glyphosate-only systems [4-6]. Growers rapidly adopted GR crop technology for reasons discussed by Culpepper and York [4], and 73, 80, and 93\% of the US corn (Zea mays L.), cotton, and soybean crops were planted to GR cultivars and hybrids in 2012 [7].

In the late 1990s, weed resistance to glyphosate was considered unlikely because of unique properties of the herbicide, such as its mechanism of action, absence of metabolic degradation in plants, and lack of residual activity in soil [8]. However, with widespread planting of GR crops and extensive reliance on glyphosate, resistant biotypes evolved. Today, resistance to glyphosate has been confirmed in 24 weed species [9]. The first confirmation of resistance to glyphosate in an Amaranthus species occurred with Palmer amaranth in Georgia in 2005 [10]. By 2012, GR Palmer amaranth had been confirmed in Alabama, Arizona, Arkansas, California, Delaware, Georgia, Illinois, Kansas, Louisiana, Michigan, Mississippi, Missouri, New Mexico, North Carolina, Ohio, Tennessee, and Virginia [9].

Resistance to glyphosate can be due to both target site and nontarget site mechanisms, and this has been reviewed recently [11, 12]. Target site resistance to glyphosate is due to altered herbicide interaction with the target enzyme, 5-enolpyruvylshikimate-3-phosphate synthase (EPSPS, E.C.2.5.1.19). This can result from gene-sequence changes that reduce sensitivity of the expressed enzyme [11]. Alternatively, target site resistance to glyphosate can 
result from increased enzyme levels due to either transient overexpression of mRNA or an increase in gene copy number [12]. Increased gene copy number was first identified in GR Palmer amaranth from Georgia [13] and later identified as a possible mechanism in GR Palmer amaranth from North Carolina [14] and GR Italian ryegrass (Lolium perenne spp. multiflorum (Lam.) Husnot) from Arkansas [15].

Nontarget site resistance to glyphosate can include altered absorption, translocation, or metabolism. Resistance to glyphosate due to altered translocation within the plant is reported to be the most common mechanism of resistance, and this mechanism has been documented in several weed species $[11,16]$. Recent research demonstrated that the mechanism of altered movement in GR horseweed (Coynza Canadensis (L.) Cronq.) and Lolium spp. was associated with vacuolar sequestration of glyphosate, resulting in reduced cytoplasmic concentration [17, 18]. Vacuolar sequestration is also associated with restricted glyphosate movement into the phloem and reduced translocation throughout the plant. The authors concluded that there was a tonoplast transporter present in the GR biotypes that moved glyphosate out of the cytoplasm, but this transporter was not present or active in GS biotypes $[17,18]$.

Glyphosate resistance is often associated with more than one mechanism. Reduced herbicide absorption has been often associated with resistance, but it is rarely the only mechanism. Until recently, glyphosate metabolism had not been detected, and thus metabolism was not thought to be a means of resistance [12]. However, glyphosate metabolism has been suggested but not confirmed as part of the mechanism of resistance $[19,20]$.

Culpepper et al. [10] suggested that altered absorption and translocation are not associated with glyphosate resistance in a Georgia biotype of Palmer amaranth when compared $48 \mathrm{~h}$ after treatment with ${ }^{14} \mathrm{C}$ label. In susceptible plants, glyphosate competes with the substrate phosphoenolpyruvate for a binding site on EPSPS, resulting in unregulated flow of carbon into the shikimate pathway and a characteristic accumulation of shikimate in sensitive tissues [21]. The Georgia GS Palmer amaranth biotype accumulated shikimate after exposure to glyphosate, compared with no accumulation in the GR biotype [10]. Gaines et al. [22] reported a 60to 120 -fold increase in gene copy number in the Georgia GR biotype, and the increase in gene copy number was correlated with the level of resistance. Resistance levels differ considerably among biotypes of Palmer amaranth collected in North Carolina and Georgia. For example, GR biotypes from Georgia have levels of resistance ranging from 3- to 8fold higher than susceptible biotypes, whereas GR biotypes from North Carolina range from 3- to 22-fold higher [23].

Comparing absorption and translocation between resistant and susceptible biotypes can be important in defining the possible mechanism of resistance for glyphosate. Additionally, methodology can vary among researchers and can contribute to variation in conclusions used in developing plausible explanations of mechanisms of resistance. Therefore, research was conducted to determine the level of resistance in a North Carolina GR Palmer amaranth biotype, to evaluate possible differences in shikimate accumulation in GR and GS biotypes following glyphosate application, and to compare absorption and translocation of ${ }^{14} \mathrm{C}$-glyphosate in the GR biotype and a GS biotype in the presence and absence of an overspray with a commercial formulation of glyphosate.

\section{Materials and Methods}

2.1. Seed Collection and Growing Conditions. Experiments were conducted in a greenhouse maintained at $32 \pm 5^{\circ} \mathrm{C}$ with natural lighting supplemented for $14 \mathrm{~h}$ by metal halide lamps (Hubbell Lighting, Inc., Greenville, SC) delivering $400 \mu \mathrm{mol} \mathrm{m}^{-2} \mathrm{~s}^{-1}$ photosynthetic photon flux density. Plants were grown in a commercial potting medium (Metro Mix 300, Sun Gro Horticulture, Bellevue, WA) and were irrigated four times daily with an automated irrigation system to maintain optimum soil moisture. Plants were fertilized with a water soluble fertilizer (Peters Professional Water Soluble 20-20-20 Fertilizer, Scotts Company, Marysville, $\mathrm{OH}$ ) as needed to maintain good growth. Glyphosate was applied using a track sprayer equipped with a single even-spray flatfan nozzle (TeeJet TP8002E Even Flat Spray Tips, TeeJet Technologies, Wheaton, IL) delivering $140 \mathrm{~L} \mathrm{ha}^{-1}$ at $275 \mathrm{kPa}$. Following herbicide application, plants were returned to the greenhouse where irrigation was withheld for $24 \mathrm{~h}$.

Palmer amaranth seeds were collected from a known GS population near Clayton, NC. Seeds for the GR biotype were collected near Parkton, NC, from plants that survived multiple applications of glyphosate during the 2006 growing season. Seedlings from the Parkton collection were grown in the greenhouse in pots 25 by $28 \mathrm{~cm}$ (depth by diameter) and treated when plants were 7 to $10 \mathrm{~cm}$ tall with glyphosate potassium salt (Roundup WEATHERMAX herbicide, $540 \mathrm{~g}$ ae glyphosate per liter, Monsanto Company, St. Louis, MO) at $1200 \mathrm{~g}$ ae ha ${ }^{-1}$. Preliminary research determined that glyphosate at $280 \mathrm{~g} \mathrm{ha}^{-1}$ was completely effective on the Clayton GS biotype. Greater than $95 \%$ of plants from the initial Parkton collection survived glyphosate application in the greenhouse. Plants from the Parkton collection surviving glyphosate application were allowed to cross-pollinate. Flowering was induced by covering 40 to $60 \mathrm{~cm}$ tall plants with black plastic for $14 \mathrm{~h}$ for five consecutive nights. Male plants were interspersed among female plants, and crosspollination was facilitated by shaking the inflorescences of male plants daily during pollination. Mature seed were collected, and the process, including glyphosate application, was repeated two additional times to obtain an $\mathrm{F} 4$ population which was used in all experiments. Seed were stored at $1^{\circ} \mathrm{C}$ until use.

\subsection{Glyphosate Dose Response and Shikimate Assay.} Seedlings of both the GR and GS biotypes were grown as previously described in pots 10 by $12 \mathrm{~cm}$ (diameter by depth) and were thinned to one seedling per pot. Glyphosate at $0,50,100,500,1000$, and $5000 \mathrm{~g} \mathrm{ha}^{-1}$ was applied when plants were 7 to $10 \mathrm{~cm}$ tall using the track sprayer previously described. Shikimic acid content of the plants was determined 5 DAT (days after treatment), and fresh weight 
of live shoot tissue was recorded 21 DAT. The experimental design was a randomized complete block with treatments replicated six times, blocking against plant size, and the experiment was repeated once.

Shikimic acid content was determined using a method modified from Shaner et al. [24]. Two leaf discs $(4 \mathrm{~mm}$ diameter) per plant were excised from the youngest, fully expanded leaves using a cork borer. Each disc was placed in an individual well of a 96-well microtiter plate that contained $100 \mu \mathrm{L}$ of buffer of $10 \mathrm{mM}$ ammonium phosphate (pH 4.4) and $0.1 \%(\mathrm{v} / \mathrm{v})$ nonionic surfactant (Tween 80 surfactant, Fisher Scientific, Pittsburg, PA). Plates were covered with a lid, sealed with a strip of Parafilm (Pechiney Plastic Packaging Co., Chicago, IL), placed in a plastic freezer bag, and stored at $-20^{\circ} \mathrm{C}$. For the analysis, plates were thawed at $60^{\circ} \mathrm{C}$ for $30 \mathrm{~min}$., and then $25 \mu \mathrm{L}$ of $1.25 \mathrm{~N} \mathrm{HCl}$ was pipetted into each well. After incubation at $60^{\circ} \mathrm{C}$ for $15 \mathrm{~min}, 25 \mu \mathrm{L}$ aliquot was transferred from each well to a separate microtiter plate, $100 \mu \mathrm{L}$ of $0.25 \%(\mathrm{w} / \mathrm{v})$ periodic acid $/ 0.25 \%(\mathrm{w} / \mathrm{v}) \mathrm{m}$ periodate solution was added to each well, and the plate was incubated at $25^{\circ} \mathrm{C}$ for $90 \mathrm{~min}$. The reaction was terminated by adding $100 \mu \mathrm{L}$ of $0.6 \mathrm{~N}$ sodium hydroxide/ $0.22 \mathrm{M}$ sodium sulfite to each well, and the optical density was measured at $380 \mathrm{~nm}$ within 30 min using a spectrophotometer ( $\mu$ Quant Microplate Spectrophotometer, BioTek Instruments, Inc., Winooski, VT). Background optical density was determined from wells containing the control discs ( 0 glyphosate rate) and was subtracted from each of the glyphosate treatments. A shikimic acid standard curve was developed by adding known amounts of shikimic acid to extracts from control leaf discs, and results are reported as micrograms shikimic acid per milliliter.

2.3. Absorption and Translocation. Seed of GR and GS biotypes were planted separately in pots containing a sandy soil with low organic matter. Plants 10 to $14 \mathrm{~cm}$ tall with 9 to 11 leaves were selected for the experiment. The experiment was conducted as a randomized complete block design with five treatments replicated six times, blocking against plant size, and the experiment was repeated once. Four treatments had a factorial arrangement based on biotype (GR and GS) and glyphosate overspray (not oversprayed or oversprayed with the previously described commercial formulation of glyphosate potassium salt at $840 \mathrm{~g} \mathrm{ha}^{-1}$ immediately before ${ }^{14} \mathrm{C}$-glyphosate application). Entire plants were oversprayed using the track sprayer described previously. The uppermost fully expanded leaf was then spotted with $10 \mu \mathrm{L}$ of ${ }^{14} \mathrm{C}$ glyphosate solution using a microapplicator. Technical grade phosphonomethyl- ${ }^{14} \mathrm{C}$-glyphosate (Sigma Chemical Co., St. Louis, MO) with $2.035 \mathrm{GBq} / \mathrm{mmol}$ specific activity and $99 \%$ radiochemical purity was used. The spotting solution contained $330 \mu \mathrm{L}$ of ${ }^{14} \mathrm{C}$-glyphosate diluted in $920 \mu \mathrm{L}$ of deionized water with $0.125 \%(\mathrm{v} / \mathrm{v})$ nonionic surfactant (Induce, Helena Chemical Company, Collierville, TN). Glyphosate dose from $10 \mu \mathrm{L}$ of spotting solution equaled $140 \mathrm{~g} \mathrm{ha}^{-1}$ based on a $10-\mathrm{cm}^{2}$ leaf (approximate size of treated leaf) and contained $6.5 \mathrm{kBq}$ of radioactivity.
Plants were harvested at $6,12,24,48$, and 72 HAT and divided into four regions: (1) treated leaf, (2) shoot above treated leaf, (3) shoot below treated leaf, and (4) roots. The treated leaf was removed at the point of attachment to the stem. This point of attachment was the basis for division of plant parts. Roots were washed over wire mesh to remove soil. Foliar absorption of glyphosate was determined by washing the treated leaf in $20 \mathrm{~mL}$ of 50:50 mixture of methanol and deionized water with $0.25 \%(\mathrm{v} / \mathrm{v})$ nonionic surfactant for $1 \mathrm{~min}$ to remove herbicide remaining on the leaf surface. One $\mathrm{mL}$ aliquots of the leaf wash were added to $15 \mathrm{~mL}$ of scintillation cocktail (ScintiVerse BD cocktail, Scintanalyzed, Fisher Scientific, Fairlawn, NJ), and radioactivity was quantified with liquid scintillation spectrometry (Packard TRICARB 2100TR Liquid Scintillation Spectrometer, Packard Instrument Company, Downers Grove, IL) (LSS). Plant parts were dried for $72 \mathrm{~h}$ at $45^{\circ} \mathrm{C}$, weighed, and combusted with a biological sample oxidizer (Model OX-500 Biological Material Oxidizer, R.J. Harvey Instrument Corp., Hillsdale, NJ). Radioactivity was quantified by LSS. Absorption was expressed as a percentage of total recovered ${ }^{14} \mathrm{C}$. Distribution of ${ }^{14} \mathrm{C}$ in each plant part was expressed as a percentage of absorbed ${ }^{14} \mathrm{C}$.

2.4. Statistical Analysis. Shoot fresh weights from the dose response experiment were converted to percent reduction relative to the control $\left(0 \mathrm{~g} \mathrm{ha}^{-1}\right.$ glyphosate). Data for shoot fresh weight reduction and shikimate production were plotted versus $\log _{10}$ herbicide doses to develop a dose response curve using SIGMAPLOT 11.2 (SigmaPlot, version 11.0, Systat Software, Inc., San Jose, CA). An $I_{50}$ value for percent reduction in fresh weight was calculated from the regression equation. Data from the absorption and translocation experiment were subjected to ANOVA with sums of squares partitioned appropriately for a 2 (overspray treatments) by 2 (Palmer amaranth biotypes) by 6 (harvest date) factorial arrangement. Experimental run was considered a random effect. Significant interaction and main effect means were separated with Fisher's Protected LSD test at $P \leq 0.05$.

\section{Results and Discussion}

3.1. Glyphosate Dose Response. The $I_{50}$ parameter estimates for percent reduction in fresh weight were 18-fold higher for the GR biotype (2,565 $\left.\mathrm{g} \mathrm{ha}^{-1}\right)$ compared with the GS biotype $\left(146 \mathrm{~g} \mathrm{ha}^{-1}\right)$ (Figure 1). This is similar to the 20 -fold difference reported by Whitaker [25] from other studies with the same seed. Levels of glyphosate resistance can vary among Palmer amaranth collections. Culpepper et al. [10] reported that GR Palmer amaranth in Georgia had a 6- to 8-fold level of resistance compared with a known GS biotype. In Arkansas, a GR biotype was reported to have between 79- and 115-fold level of resistance [26], while Steckel et al. [27] reported a 1.5to 5-fold level of glyphosate resistance in Palmer amaranth collected in Tennessee. Although these results suggest that resistance likely evolved independently across geographical regions and that mechanisms of resistance may vary among populations, differences in resistance levels among states 


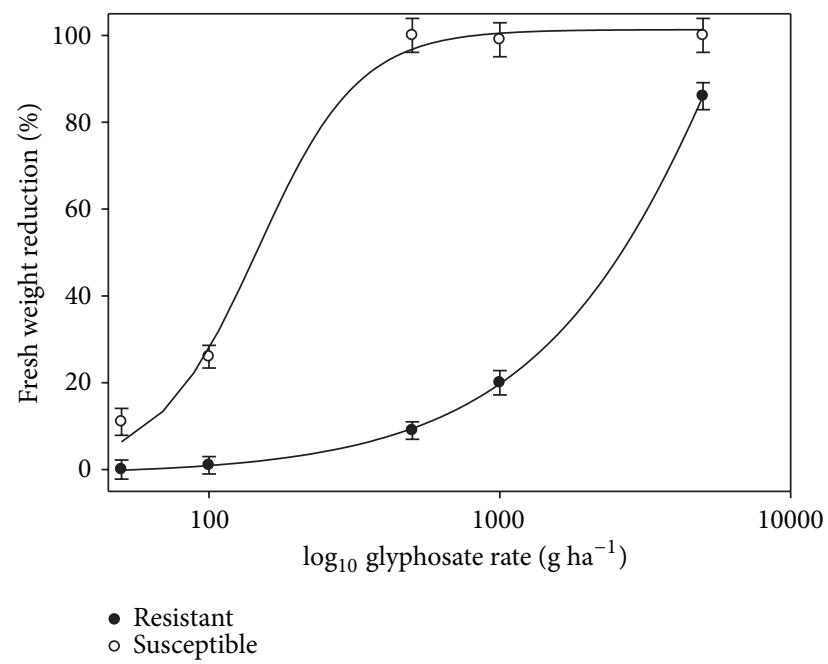

Figure 1: Percent reduction in Palmer amaranth fresh weight of glyphosate-resistant and glyphosate-susceptible biotypes 21 days after glyphosate application. Data are pooled over two experiments. Regression expressions are resistant biotype, $Y=0.000001 x^{2}+$ $0.02 x-1.3, r^{2}=0.99$; susceptible biotype, $Y=101 /\left(1+(x / 146)^{-2.5}\right)$, $r^{2}=0.99$.

may also reflect differences in methodology. In Arkansas, resistance levels were based upon the amount of glyphosate needed to cause $50 \%$ mortality, while in Georgia, North Carolina, and Tennessee they were based on visible control estimates or shoot fresh weight reduction. Other factors, including the sensitivity of the GS biotypes and the methodology regarding GR seed selection, also may have played a role in determining the level of resistance. In the Arkansas study, GS Palmer amaranth seed was collected from a South Carolina field with no history of glyphosate use [26]. Seed of the GS biotype in North Carolina was collected from a field that had been treated with glyphosate at least once per year for several consecutive years, but glyphosate consistently controlled the Palmer amaranth completely in that field.

3.2. Shikimate Assay. The shikimate concentration was low $\left(<10 \mu \mathrm{g} \mathrm{mL}^{-1}\right)$ and similar in both biotypes treated with glyphosate at $50 \mathrm{~g} \mathrm{ha}^{-1}$ (Figure 2). Shikimate increased in both biotypes as glyphosate concentration increased, but the increase was greater in the GS biotype. At glyphosate rates of $100 \mathrm{~g} \mathrm{ha}^{-1}$ or more, shikimate concentration was always greater in the susceptible biotype. Shikimate accumulation in the GR biotype suggests unaltered EPSPS [28]. Steckel et al. [27] also reported that shikimate accumulated in both GR and GS biotypes of Palmer amaranth collected from Tennessee. Glyphosate resistance in a Georgia GR Palmer amaranth has been attributed to gene amplification and a resulting overexpression of EPSPS [29]. When inheritance of resistance was studied in this Georgia biotype, the F1 progeny had variable levels of shikimate accumulation, which was correlated with variable EPSPS copy number [29]. Chandi et al. [14] reported variable EPSPS copy number when comparing the same GR biotype used in the current study.

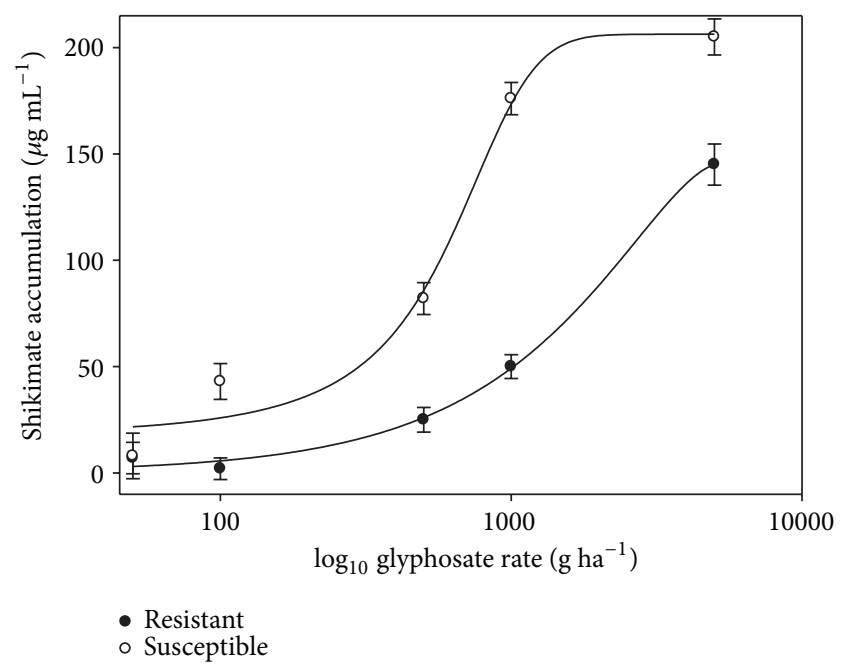

FIGURE 2: Shikimate accumulation by glyphosate-resistant and glyphosate-susceptible Palmer amaranth $5 \mathrm{~d}$ after glyphosate application. Data are pooled over two experiments. Regression expressions are resistant biotype, $Y=0.000001 x^{2}+0.01 x-0.36, r^{2}=0.99$; susceptible biotype, $Y=145 /\left(1+e^{-((x-1246) / 406)}\right), r^{2}=0.99$.

With an increased EPSPS copy number, one would expect shikimate to accumulate but at a lesser rate than observed in the GS biotype.

3.3. Absorption and Translocation. The effect of application rate on glyphosate absorption and translocation has been studied in both GR and GS plants, and the results varied with the mechanism of resistance. In GR horseweed, where resistance was attributed to reduced translocation, the amount of glyphosate translocated in GR plants was less than in GS plants regardless of application rate [30]. When the mechanism of glyphosate resistance is due to an insensitive EPSPS, the translocation pattern is more complicated when the application rate changes [31]. Absorption and translocation were, therefore, observed over time in GR and GS Palmer amaranth biotypes at different application rates.

Approximately $86 \%$ of the total applied ${ }^{14} \mathrm{C}$-label was recovered from leaf washes and oxidized plant parts. Interactions of Palmer amaranth biotype by harvest time and glyphosate overspray by harvest time were significant. Maximum absorption was observed in the GS and GR biotypes at 6 and 12 HAT, respectively (Table 1). The GS plants absorbed $67 \%$ more glyphosate than GR plants 6 HAT. However, absorption by both biotypes was similar at 12 to 72 hours (25 to 35\%). Glyphosate absorption in this experiment was similar to that previously observed in Palmer amaranth. Culpepper et al. [10] reported 31 to $36 \%$ absorption 48 HAT, while Grey et al. [32] reported 44\% absorption 24 HAT. The role of a slower rate of glyphosate absorption in GR versus GS was surprising based on previous research, and the impact of this finding on better understanding of the mechanism or mechanisms of glyphosate resistance in Palmer amaranth is not known. 
TABLE 1: Absorption of ${ }^{14} \mathrm{C}$-glyphosate as affected by Palmer amaranth biotype and glyphosate overspray ${ }^{\mathrm{a}}$.

\begin{tabular}{lcccc}
\hline $\begin{array}{l}\text { Harvest } \\
\text { time }\end{array}$ & \multicolumn{2}{c}{ Biotype $^{\mathrm{b}}$} & \multicolumn{2}{c}{ Glyphosate overspray $^{\mathrm{c}}$} \\
\hline $\mathrm{h}$ & Resistant & Susceptible & Not oversprayed & Oversprayed \\
6 & $18^{\mathrm{c}}$ & $30^{\mathrm{ab}}$ & $22^{\mathrm{d}}$ & $25^{\mathrm{cd}}$ \\
12 & $35^{\mathrm{a}}$ & $30^{\mathrm{ab}}$ & $36^{\mathrm{ab}}$ & $29^{\mathrm{bcd}}$ \\
24 & $32^{\mathrm{ab}}$ & $25^{\mathrm{bc}}$ & $26^{\mathrm{cd}}$ & $31^{\mathrm{abc}}$ \\
48 & $32^{\mathrm{ab}}$ & $31^{\mathrm{ab}}$ & $26^{\mathrm{cd}}$ & $36^{\mathrm{ab}}$ \\
72 & $32^{\mathrm{ab}}$ & $33^{\mathrm{ab}}$ & $25^{\mathrm{cd}}$ & $40^{\mathrm{a}}$ \\
\hline
\end{tabular}

${ }^{a}$ Absorption expressed as percentage of total ${ }^{14} \mathrm{C}$ recovered. Means within the effect of biotype or glyphosate overspray followed by the same letter are not different according to Fisher's Protected LSD at $P \leq 0.05$.

${ }^{\mathrm{b}}$ Data pooled over glyphosate overspray options.

${ }^{c}$ Data pooled over glyphosate-resistant and glyphosate-susceptible biotypes. Glyphosate applied at $840 \mathrm{~g} / \mathrm{ha}$.

Overspraying plants with glyphosate affected ${ }^{14} \mathrm{C}$ glyphosate absorption. Absorption was similar during the first 24 hours regardless of overspray (Table 1). However, plants oversprayed with glyphosate absorbed 38 and $60 \%$ more ${ }^{14} \mathrm{C}$-glyphosate 48 and $72 \mathrm{HAT}$, respectively, than plants not oversprayed. This difference in absorption was likely associated with the adjuvant package in the commercial glyphosate formulation used to overspray compared to $0.125 \%(\mathrm{v} / \mathrm{v})$ nonionic surfactant included in the ${ }^{14} \mathrm{C}$ glyphosate spotting solution. Li et al. [33] reported that glyphosate absorption by common waterhemp (Amaranthus rudis Sauer) was affected by glyphosate formulation. Differences in absorption and translocation observed when plants were oversprayed versus plants receiving only treatment of a single leaf also may have been associated with changes in physiology caused by glyphosate within the first few days after treatment. The experimental procedure was insufficient to delineate between formulation and adjuvant contributions to ${ }^{14} \mathrm{C}$ absorption and translocation versus overall changes in physiology caused by glyphosate mode of action.

Main effects and interactions for biotype, glyphosate overspray, and harvest time were not significant for ${ }^{14} \mathrm{C}$ distribution in the plants. In both biotypes, 40 to $43 \%$ of ${ }^{14} \mathrm{C}$ applied remained in the treated leaf, while 30 to 31, 22, and 5 to $7 \%$ were found in shoot tissue above the treated leaf, shoot tissue below the treated leaf, and roots, respectively (data not shown).

\section{Conclusions}

Results of this experiment indicate that glyphosate resistance in the North Carolina Palmer amaranth biotype examined is not due to limited absorption or translocation of glyphosate. Both glyphosate absorption into the treated leaf and translocation to meristematic areas in the GR biotype were similar to or greater than in the GS biotype by 12 HAT. The role of a slower rate of glyphosate absorption in the GR biotype compared with the GS biotype 6 HAT is not known with respect to resistance mechanisms. Shikimate accumulation at higher rates of glyphosate suggests that resistance is not due to an altered EPSPS. Together, these results support a mechanism of increased EPSPS gene copy number, an observation reported by Chandi et al. [14] for this biotype.

\section{Conflict of Interests}

None of the authors has a conflict of interests in terms of the products mentioned in the paper.

\section{References}

[1] T. M. Webster, "Weed survey: southern states," Proceedings Southern Weed Science Society, vol. 62, pp. 509-524, 2009.

[2] J. A. Bond, L. R. Oliver, and D. O. Stephenson IV, "Response of Palmer amaranth (Amaranthus palmeri) accessions to glyphosate, fomesafen, and pyrithiobac," Weed Technology, vol. 20, no. 4, pp. 885-892, 2006.

[3] J. L. Corbett, S. D. Askew, W. E. Thomas, and J. W. Wilcut, "Weed efficacy evaluations for bromoxynil, glufosinate, glyphosate, pyrithiobac, and sulfosate," Weed Technology, vol. 18, no. 2, pp. 443-453, 2004.

[4] A. S. Culpepper and A. C. York, "Weed management and net returns with transgenic, herbicide-resistant, and nontransgenic cotton (Gossypium hirsutum)," Weed Technology, vol. 13, no. 2, pp. 411-420, 1999.

[5] A. S. Culpepper, A. C. York, R. B. Batts, and K. M. Jennings, "Weed management in glufosinate- and glyphosate-resistant soybean (Glycine max)," Weed Technology, vol. 14, no. 1, pp. 77$88,2000$.

[6] R. C. Scott, S. D. Askew, and J. W. Wilcut, "Glyphosate systems for weed control in glyphosate-tolerant cotton (Gossypium hirsutum)," Weed Technology, vol. 16, pp. 191-198, 2002.

[7] United States Department of Agriculture-Economic Research Service [USDA-ERS], "Adoption of Genetically Engineered Crops in the US," 2012, http://www.ers.usda.gov/data-products/adoption-genetically-engineered-crops-in-the-us.aspx.

[8] L. D. Bradshaw, S. R. Padgette, S. L. Kimball, and B. H. Wells, "Perspectives on glyphosate resistance," Weed Technology, vol. 11, no. 1, pp. 189-198, 1997.

[9] I. Heap, "The International Survey of Herbicide Resistant Weeds," 2012, http://www.weedscience.org.

[10] A. S. Culpepper, T. L. Grey, W. K. Vencill et al., "Glyphosateresistant Palmer amaranth (Amaranthus palmeri) confirmed in Georgia," Weed Science, vol. 54, no. 4, pp. 620-626, 2006.

[11] S. B. Powles and Q. Yu, "Evolution in action: plants resistant to herbicides," Annual Review of Plant Biology, vol. 61, pp. 317-347, 2010.

[12] D. L. Shaner, R. B. Lindenmeyer, and M. H. Ostlie, "What have the mechanisms of resistance to glyphosate taught us?" Pest Management Science, vol. 68, no. 1, pp. 3-9, 2012.

[13] T. A. Gaines, W. Zhang, D. Wang et al., "Gene amplification confers glyphosate resistance in Amaranthus palmeri," Proceedings of the National Academy of Sciences of the United States of America, vol. 107, no. 3, pp. 1029-1034, 2010.

[14] A. Chandi, S. R. Milla-Lewis, D. Giacomni et al., "Inheritance of evolved glyphosate resistance in a North Carolina Palmer amaranth (Amaranthus palmeri) biotype," International Journal of Agronomy, vol. 2012, Article ID 176108, 7 pages, 2012. 
[15] R. A. Salas, F. E. Dayan, Z. Pan et al., "EPSPS gene amplification in glyphosate-resistant Italian ryegrass (Lolium perenne ssp. multiflorum) from Arkansas," Pest Management Science, vol. 68, pp. 1223-1230, 2012.

[16] D. L. Shaner, "Role of translocation as a mechanism of resistance to glyphosate," Weed Science, vol. 57, no. 1, pp. 118-123, 2009.

[17] X. Ge, D. A. D’Avignon, J. J. H. Ackerman et al., "Vacuolar glyphosate-sequestration correlates with glyphosate resistance in ryegrass (Lolium spp.) from Australia, South America, and Europe: a ${ }^{31}$ P NMR investigation," Journal of Agricultural and Food Chemistry, vol. 60, no. 5, pp. 1243-1250, 2012.

[18] X. Ge, D. A. d' Avignon, J. J. H. Ackerman, and R. Douglas Sammons, "Rapid vacuolar sequestration: the horseweed glyphosate resistance mechanism," Pest Management Science, vol. 66, no. 4, pp. 345-348, 2010.

[19] F. González-Torralva, A. M. Rojano-Delgado, M. D. Luque de Castro, N. Mülleder, and R. De Prado, "Two non-target mechanisms are involved in glyphosate-resistant horseweed (Conyza canadensis L. Cronq.) biotypes," Journal of Plant Physiology, vol. 169, no. 17, pp. 1673-1679, 2012.

[20] L. B. de Carvalho, P. L. D. C. A. Alves, F. González-Torralva et al., "Pool of resistance mechanisms to glyphosate in Digitaria insularis," Journal of Agricultural and Food Chemistry, vol. 60, no. 2, pp. 615-622, 2012.

[21] N. Amrhein, B. Deus, P. Gehrke, and H. C. Steinrucken, “The site of inhibition of the shikimate pathway by glyphosate. II. Interference of glyphosate with chorismate formation in vivo and in vitro," Plant Physiology, vol. 66, pp. 830-834, 1980.

[22] T. A. Gaines, D. L. Shaner, S. M. Ward, J. E. Leach, C. Preston, and P. Westra, "Mechanism of resistance of evolved glyphosateresistant palmer amaranth (Amaranthus palmeri)," Journal of Agricultural and Food Chemistry, vol. 59, no. 11, pp. 5886-5889, 2011.

[23] A. S. Culpepper, J. R. Whitaker, A. W. MacRae, and A. C. York, "Weed science: distribution of glyphosate-resistant palmer amaranth (Amaranthus palmeri) in Georgia and North Carolina during 2005 and 2006," Journal of Cotton Science, vol. 12, no. 3, pp. 306-310, 2008.

[24] D. L. Shaner, T. Nadler-Hassar, W. B. Henry, and C. H. Koger, "A rapid in vivo shikimate accumulation assay with excised leaf discs," Weed Science, vol. 53, no. 6, pp. 769-774, 2005.

[25] J. R. Whitaker, Distribution, Biology, and Management of Glyphosate-Resistant Palmer Amaranth in North Carolina [Ph.D. thesis], North Carolina State University, Raleigh, NC, USA, 2009.

[26] J. K. Norsworthy, G. M. Griffith, R. C. Scott, K. L. Smith, and L. R. Oliver, "Confirmation and control of glyphosate-resistant Palmer amaranth (Amaranthus palmeriAmaranthus palmeri) in Arkansas," Weed Technology, vol. 22, no. 1, pp. 108-113, 2008.

[27] L. E. Steckel, C. L. Main, A. T. Ellis, and T. C. Mueller, "Palmer amaranth (Amaranthus palmeri) in Tennessee has low level glyphosate resistance," Weed Technology, vol. 22, no. 1, pp. 119123, 2008.

[28] T. C. Mueller, J. H. Massey, R. M. Hayes, C. L. Main, and C. N. Stewart Jr., "Shikimate accumulates in both glyphosatesensitive and glyphosate-resistant horseweed (Conyza canadensis L. Cronq.)," Journal of Agricultural and Food Chemistry, vol. 51, no. 3, pp. 680-684, 2003.

[29] T. A. Gaines, D. L. Shaner, S. M. Ward, J. E. Leach, C. Preston, and P. Westra, "Mechanism of resistance of evolved glyphosateresistant palmer amaranth (Amaranthus palmeri)," Journal of
Agricultural and Food Chemistry, vol. 59, no. 11, pp. 5886-5889, 2011.

[30] P. C. C. Feng, M. Tran, T. Chiu, R. D. Sammons, G. R. Heck, and C. A. Cajacob, "Investigations into glyphosate-resistant horseweed (Conyza canadensis): retention, uptake, translocation, and metabolism," Weed Science, vol. 52, no. 4, pp. 498-505, 2004.

[31] P. R. Hetherington, T. L. Reynolds, G. Marshall, and R. C. Kirkwood, "The absorption, translocation and distribution of the herbicide glyphosate in maize expressing the CP-4 transgene," Journal of Experimental Botany, vol. 50, no. 339, pp. 1567-1576, 1999.

[32] T. L. Grey, L. M. Sosnoskie, A. M. Wise, and W. K. Vencill, "Distribution of ${ }^{14} \mathrm{C}$-glyphosate in glyphosate-resistant Palmer amaranth (Amaranthus palmeri)," Proceedings Southern Weed Science Society, vol. 61, p. 202, 2008.

[33] J. Li, R. J. Smeda, B. A. Sellers, and W. G. Johnson, "Influence of formulation and glyphosate salt on absorption and translocation in three annual weeds," Weed Science, vol. 53, no. 2, pp. 153-159, 2005. 


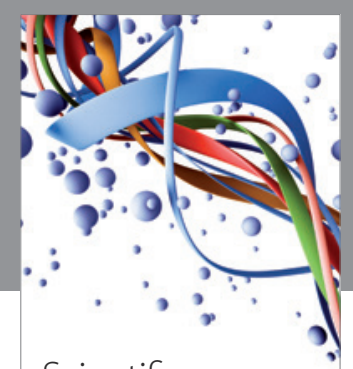

Scientifica
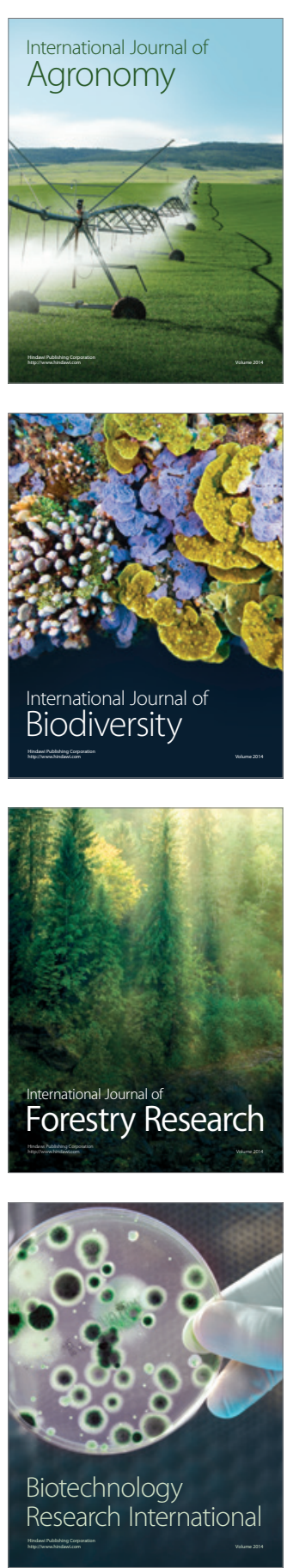
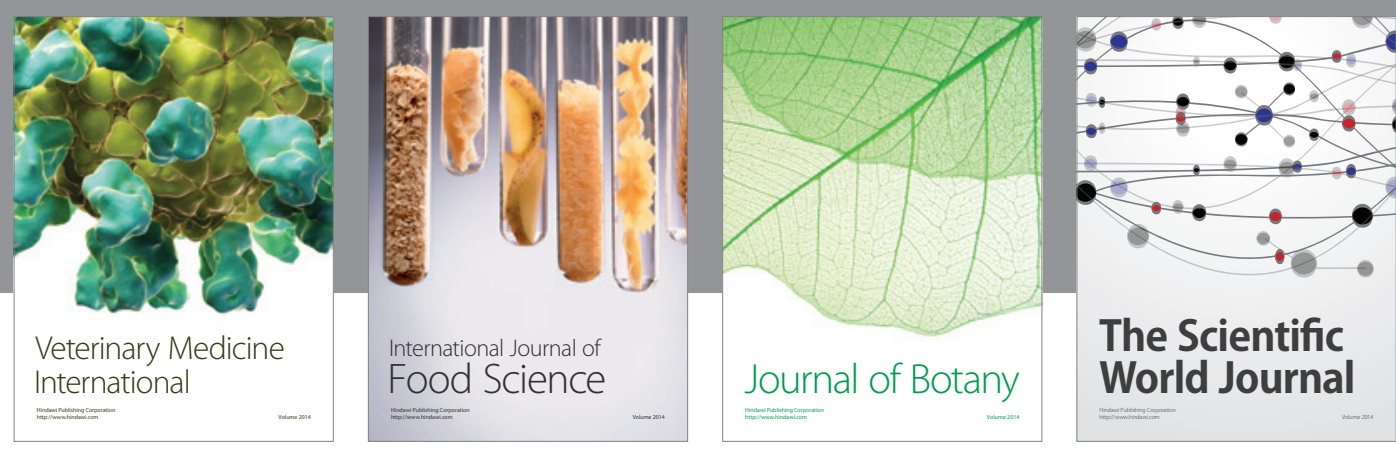

The Scientific World Journal
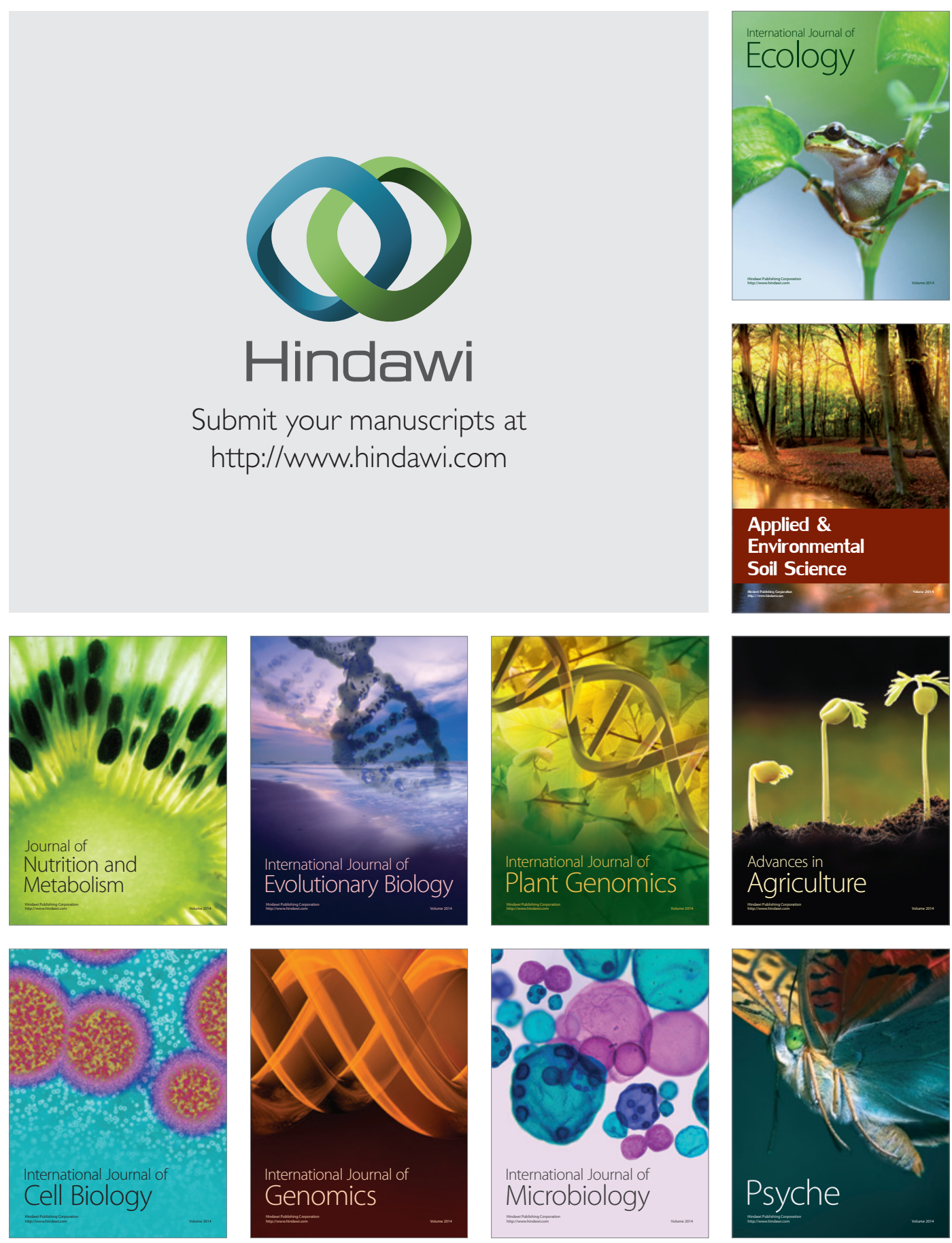